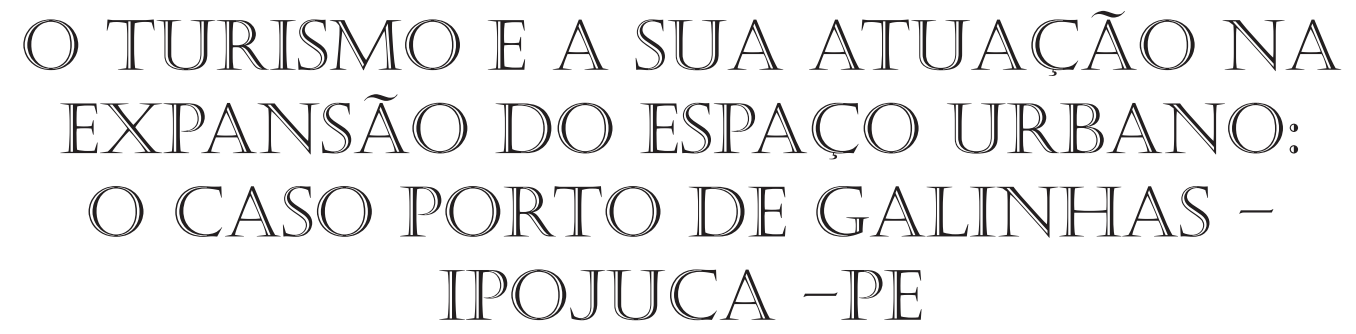

TOURISM AND ITS ROLE IN THE EXPANSION OF THE URBAN SPACE: THE CASE OF PORTO DE GALINHAS - IPOJUCA-PE

EL TURISMO Y SU PAPEL EN LA EXPANSIÓN DEL ESPACIO URBANO: EL CASO PORTO DE GALINHAS - IPOJUCA -PE

\title{
Danielle Mesquita
}

Gilca Xavier

Data de Submissão: 06/07/2012

Data de Aprovação: 07/05/2013

\section{RESUMO}

Este trabalho visa identificar a influência do turismo na expansão do espaço urbano de Porto de Galinhas. No decorrer da formação do seu território, Porto de Galinhas, a 50 km da capital pernambucana, passou por diversas modificações espaciais, sociais, econômicas, entre outras, devido a uma necessidade local e ocorrendo, posteriormente, pelo intenso desenvolvimento do turismo. Constituída de poucas casas de pescadores e fazendas de coco, atualmente, Porto de Galinhas concentra diversos estabelecimentos predominantemente voltados ao turismo. Para fins do estudo, a área estudada foi Porto de Galinhas e o período entre 1970 a 2011 , correspondendo, respectivamente, ao início da atividade de veraneio no local até a sua consolidação como destino internacional. Houve a coleta de dados primários e secundários relacionados ao tema deste trabalho e o cruzamento destes dados com os indicadores utilizados e pontos discutidos no referencial teórico deste estudo. Por meio da pesquisa, foi observado que o turismo incentivou a intensa expansão do espaço urbano em Porto de Galinhas, por meio do surgimento e da ampliação de estabelecimentos comerciais e investimento na infraestrutura básica e turística. No entanto sua atuação também resultou na ocorrência da segregação socioespacial e no aumento das disparidades socioeconômicas, sobretudo nas áreas periféricas.

PALAVRAS-CHAVE: Turismo. Expansão do espaço urbano. Porto de Galinhas.

\section{ABSTRACT}

This work aims to identify the influence of tourism on the development of the urban space of Porto de Galinhas. During the formation of its territory, Porto has undergone many spatial, social and economic changes, among others, due to a local need, and subsequently, following the intense development of tourism. Consisting of a few fishermen's houses and coconut farms, Porto de Galinhas currently has several establishments focusing predominantly on tourism. For purposes of this study, the area studied was Porto de Galinhas, and the period was 1970 to 2011, which corresponds to the start of summer activities in the region through to its consolidation as an international destination. Primary and secondary data were collected relating to the theme of this work, and these data were cross-referenced against the indicators used in this study. Through the research, it was observed that tourism has encouraged the intense expansion of the urban space in Porto de Galinhas, through the emergence and expansion of businesses and investments in basic infrastructure and tourism. However, these actions have also resulted in sociospatial segregation and increasing socioeconomic disparities, especially in the peripheral areas. 
KEYWORDS: Tourism. Urban expansion. Porto de Galinhas.

\section{RESUMEN}

Este trabajo se propone identificar la influencia del turismo en la expansión del espacio urbano de Porto de Galinhas. En el transcurso de la formación de su territorio, Porto de Galinhas, a 50 km de la capital pernambucana, pasó por diversas modificaciones espaciales, sociales, económicas, entre otras, debido a una necesidad local y motivada, posteriormente, por el intenso desarrollo del turismo. Constituida por pocas casas de pescadores y plantaciones de coco, actualmente Porto de Galinhas concentra diversos establecimientos dedicados predominantemente al turismo. Para fines de estudio el área estudiada fue Porto de Galinhas y el período fue el comprendido entre 1970 y 2011, correspondiendo, respectivamente, al inicio de la actividad de veraneo en el local hasta su consolidación como destino internacional. Se realizó la recolección de datos primarios y secundarios relacionados al tema de este trabajo y el cruzamiento de estos datos con los indicadores utilizados y puntos discutidos en el referente teórico de este estudio. Por medio de la investigación se observó que el turismo estimuló la intensa expansión del espacio urbano en Porto de Galinhas a través del surgimiento y de la ampliación de establecimientos comerciales e inversiones en la infraestructura básica y turística. Sin embargo, su actuación también provocó una segregación socioespacial y un aumento de las disparidades socioeconómicas, sobre todo en las áreas periféricas.

PALABRAS ClAVE: Turismo. Expansión del espacio urbano. Porto de Galinhas.

\section{INTRODUÇÃO}

A formação e a expansão de um território ocorrem devido a diversos fatores, como a sua história, atuação de seus atores sociais, atividade econômica, entre outros. Nas várias análises sobre o assunto, o turismo constitui-se uma atividade que exerce influência no território, gerando inter-relações tanto no aspecto social, econômico, cultural e ambiental.

Quando atuante em espaços litorâneos, geralmente o turismo surge a partir da atividade de veraneio e da implantação de meios de hospedagens de pequeno e grande porte, gerando o investimento na infraestrutura básica e turística, ao mesmo tempo que pode causar a especulação imobiliária e a segregação socioespacial.

Nesse contexto, Porto de Galinhas, localizado no município de Ipojuca, é considerado um dos principais destinos turísticos pernambucanos. Em aproximadamente 40 anos, foi palco de uma reestruturação urbana, sobretudo pela implantação da atividade turística.

Por isso, este trabalho tem o objetivo de investigar a influência do turismo na expansão do espaço urbano de Porto de Galinhas. O trabalho se reporta ao período de 1970 até 2011, a partir do início do veraneio organizado em Porto de Galinhas até a sua consolidação como um destino internacional. Para isso, foram realizadas entrevistas com os residentes e os representantes governamentais, coleta de dados secundários relacionados ao tema e o cruzamento dos dados com os indicadores utilizados neste estudo.

\section{O TURISMO E A PRODUÇÃO DO ESPAÇO URBANO}

\section{TERRITÓRIO E ESPAÇO - CONCEITO E FORMAÇÃO}

Território consiste em um objeto de estudo social, devido ao seu uso, não por sua delimitação, fruto do processo histórico e cultural que define a sua configuração a partir da identidade dos seus atores sociais e de suas singularidades (RODRIGUES, 2007), baseado na economia, na política e no social, a partir da sua apropriação, pela sociedade, em um determinado período, influenciado pelos seus interesses e necessidades (BECKER, 1983). 
Território pode ser um espaço socialmente equitativo, pela ação e cooperação dos seus atores, a partir da autonomia na manifestação de suas escolhas e potencialidades (SOUZA, 2001); como marcado pelas contradições sociais, devido à heterogeneidade de ordem econômica, política e cultural existente, causada pela produção da qual é arcabouço (SANTOS, 1996), podendo ser minimizada a partir da livre atuação dos seus atores (SAQUET, 2004). Diante disso, pode-se dizer que existe uma relação intrínseca entre poder e território, pois é resultado da dinâmica, produção, consumo, vivência e atuação destes atores, por meio das relações de poder de escalas variantes existentes no território (RASFETIN, 1993), que determina a forma de desenvolvimento do local.

Existem locais que se centralizam em uma atividade econômica e na atuação de um ou poucos atores locais, incorporando estas dinâmicas na configuração do seu espaço. Nesse contexto, Andrade (1995) e Colbert e Golbery apud Santos (2005) afirmam que o poder e o controle do Estado resultaram na definição e no molde do território, tornando-o subordinado a esta instituição. Posteriormente, o que era um Estado Nacional para ser algo transnacionalizado, com a criação de novas sinergias, por meio das redes, onde os mesmos lugares contêm funções diferentes e até opostas (JACQUES BOUDEVILLE apud SANTOS, 2005).

Nestes dois primeiros casos, a formação territorial é estabelecida por regras intrínsecas, com a atuação de forças centrípetas locais, constituída de interesses do próprio território, enquanto que o hierárquico é regido por uma força centrífuga, formada pelo domínio de uma força externa deste local. Nesse sentido, há duas forças que regem a formação do território, interferindo na sua formação para atendê-las. Vale salientar que a atuação de atores e fatores exógenos, bem como a desarticulação territorial interna do território, pode ocasionar a falta de atendimento à demanda local.

Já o espaço transcende o território, construído e adaptado a partir das relações sociais, valores e costumes da sociedade, ao mesmo tempo em que as novas formas e processos deste espaço geram mudança na sociedade (CARLOS, 1999). Da mesma forma que a sociedade é marcada pelas injustiças sociais, o espaço é reflexo das contradições e dos conflitos de interesse (SANTOS, 1996). Por isso, espaço e sociedade também possuem uma estreita ligação, já que o primeiro acompanha as transformações do segundo.

A respeito do espaço urbano, sua definição e caracterização levam em consideração o seu uso, de acordo com diversas atividades (comércio, serviços, gestão, áreas industriais, residenciais, públicas, privadas e de lazer) (CORRÊA, 2002). Assim, o uso do solo admite uma variedade de atividades da própria sociedade, com os seus respectivos padrões ou tipos de assentamentos que atuam em um determinado local, definindo a função e o uso que se faz deste espaço, adaptando-o (DEÁK, 1985).

\section{URBANIZAÇÃO}

Urbanização é o crescimento e a modernização das cidades, resultando no aumento dos fluxos migratórios e na concentração da população (SELVA, 1988). Consiste na expansão urbana em áreas rurais (JACQUIN et al, 2008), a partir da inserção de características urbanas em um espaço, na implementação de infraestrutura, equipamentos e serviços urbanos (água, esgoto, eletricidade, transporte, educação e saúde), importantes para o desenvolvimento das cidades (SPOSITO, 1991 apud FONSECA; COSTA, 2004).

A urbanização e sua dinâmica relacionam-se com a história, a formação, o crescimento e o desenvolvimento de um território e espaço, sendo entendida como um processo e uma função (SANTOS, 1993), intimamente ligada às relações comportamentais ocorridas na sociedade por meio das transformações, muitas vezes, profundas e irreversíveis, decorrentes deste processo, afetando aspectos da vida social da sociedade. Resulta na geração e na acentuação das desigualdades socioespaciais, quando não acompanhada do aumento e da distribuição dos investimentos em infraestrutura e maior acesso aos serviços urbanos (COELHO, 2001). Além disso, tem forte ligação com o desenvolvimento socioeconômico local, com limitações referentes à situação social, de pobreza local e das suas dificuldades geográficas (XAVIER, 2005). Além disso, pela própria diversidade na função e nos usos destes locais e por ser condicionada a interesses locais, nacionais e globais, a urbanização também se torna heterogênea e excludente, atendendo a uma ou a poucas funções e usos. 
Geralmente, esse processo também é incentivado pelo poder público, quando este atua, sobretudo, na inserção de infraestrutura, cobrada pela iniciativa privada existente no local, necessária para a viabilização e para a melhoria dos seus empreendimentos, levando ao surgimento de uma cidade desigual e fragmentada. Além disso, a limitação da intervenção pública e o aumento da mobilidade de capital estrangeiro levam ao aumento do processo de mercantilização do desenvolvimento urbano, bem como das desigualdades e das novas modalidades de fragmentação urbana. Nesse sentido, o setor privado realiza investimentos, visando aproveitar oportunidades oferecidas por cada cidade para a realização dos seus negócios, sem pensar no desenvolvimento local (MATTOS, 2007).

A economia global e a sua complexidade nas transações, devido ao crescimento dos fluxos financeiros internacionais, requerem uma constante busca da estabilidade, em meio a crises e desigualdades, levando a alteração na função das cidades e exigindo uma infraestrutura de serviços especializados e concentração de recursos (SASSEN, 1998). Nesse sentido, a formação e a organização do território podem ser influenciadas por uma ou mais de uma atividade econômica, levando a um processo de urbanização e expansão do espaço urbano de acordo com a sua demanda e necessidade de consumo e produção. A partir dessa atuação, em vez de gerar melhorias, a atividade econômica geralmente leva ao surgimento de disparidades.

Os locais que são caracterizados por concentrarem uma atividade comercial tornam-se lugares de consumo, causando o deslocamento da parcela pobre da população para periferia e, posteriormente, da burguesia para o subúrbio, por serem áreas mais recomendadas para residir, já que são mais afastadas dos centros (LEFEBVRE, 1991). Essa realidade é encontrada na formação territorial em regiões periféricas. No Brasil, por exemplo, o processo de acumulação urbana ocorre na existência do crescimento do mercado imobiliário e esse movimento de acumulação se dá em detrimento da segregação socioespacial, na qual a população pobre continua sendo empurrada para as periferias das cidades e a venda na natureza emerge como mercadoria de grande valor de marketing dos empreendimentos (LEAL, 2010).

A economia tem interferido em diversos aspectos, devido à constante busca da estabilidade econômica, por parte das localidades. O turismo surge como uma alternativa de desenvolvimento, como a principal ou umas das principais atividades econômicas. Nesse contexto, diversas áreas litorâneas tornaram-se destinos turísticos, por conter características propícias ao desenvolvimento do turismo "sol e mar" e pela vantagem de o turismo propiciar um retorno econômico em curto prazo.

\section{TURISMO E URBANIZAÇÃO}

Em relação à urbanização, o turismo possui uma relação muito estreita, requerendo uma infraestrutura que o auxilie em seu desenvolvimento. O turismo contemporâneo desenvolve-se em lugares frágeis e de beleza considerável, devido à constante busca do verde e da fuga dos tumultos dos grandes centros urbanos, visando ao contato com o ambiente natural e à busca do equilíbrio psicofísico nos tempos de lazer (RUSCHMANN, 2000).

Nesse sentido, quando utiliza os recursos naturais, por meio do uso desordenado do espaço e da sobrecarga de demanda no local, o turismo também pode causar diversos efeitos negativos, como a deterioração de ambientes naturais para a implantação de projetos turísticos que atendam aos padrões vinculados a países do primeiro mundo, alteração das sociedades locais pela introdução de novos valores, entre outros (BECKER, op. cit.).

A especulação imobiliária, a partir da utilização e do aumento significativo do valor do solo, também é incentivada a partir do desenvolvimento da atividade, causando o surgimento de rivalidades entre os diferentes grupos de interesse (visitantes, residentes e empresários) para a sua utilização. Além disso, as áreas que mais recebem turistas geralmente começam a ser redefinidas a partir das características deste público, com novas materialidades, como galerias, shoppings, lojas de grife, etc., e implantação de resorts e condomínios fechados, tornando-se uma espécie de mercadoria para a atração de visitantes, de forma que o local, antes público, passa a ser privado (RUSCHMANN, 2004).

Este fato confirma que o turismo, principalmente em zonas costeiras, tem sido um dos maiores responsáveis pelos impactos negativos, já que assume características massivas, sendo este 
processo caracterizado pela urbanização turística (formas específicas de produção do espaço urbano engendradas a partir do turismo, sobretudo quando se torna dominante na economia local) (MULLINS, 1991).

A urbanização turística promove uma completa reorganização espacial, o que pode acentuar as desigualdades e a segregação socioespacial (SOUZA, 2006). As cidades urbanizadas turisticamente possuem características diferenciadas em relação ao crescimento demográfico, à urbanização, aos setores econômicos da economia urbana, aos níveis de emprego e subemprego, entre outros, interferindo até no uso do solo e na morfologia urbana, regidas pelos interesses do mercado imobiliário, quando há a prática do "higienismo", com a retirada de aspectos locais que são considerados inconvenientes às áreas turísticas. Não há a organização para o atendimento das necessidades básicas como moradia, serviços de saúde, educação, etc., e sim para o consumo de bens e serviços de lazer e quase que exclusivamente ao consumo de artigos e serviços de entretenimento (MASCARENHAS, 2004).

A expansão proveniente do turismo também pode ser observada por meio da construção de vias e rodovias e ampliação da malha urbana, investimentos em infraestrutura urbana e um maior oferecimento de bens e serviços, visando à permanência dos visitantes. Desse modo, pode-se dizer que o crescimento de alguns setores como hospedagens, alimentos e bebidas e transportes, junto à consolidação e à formação de uma classe consumidora de produtos turísticos, deu origem a diferentes fluxos, resultando em uma nova ordem no processo de ocupação do espaço, observando que cada vez há menos território sem turistas (TELES, 2006). A organização espacial pode ser modificada em função das alterações da demanda (CASTILHO, 1999) e o prevalecimento do consumo entre as atividades produtivas, pois, mesmo com o dinamismo econômico, é característico o subemprego, a baixa renumeração e a precarização dos contratos, o segmento com expressivo número de artesãos, os donos de pousadas, os restaurantes e bares, as lojas, entre outros (MULLINS, op. cit).

Geralmente estes locais obedecem a uma demanda externa (modelos internacionais de urbanização turística), caracterizando-se pela concentração, em áreas privilegiadas, de equipamentos voltados para o turismo e para o consumo, levando ao incentivo da urbanização local novos padrões de uso e ocupação do solo e na separação entre visitantes e residentes (LIMA, 2006).

Diversos lugares que eram vilas de pescadores e portos transformaram-se em destinos turísticos consolidados nacional e internacionalmente, com a implantação de estabelecimentos turísticos de pequeno a grande porte, segundas residências e novas práticas marítimas ligadas ao veraneio e ao turismo (BERNAL, s.d.), além da forte presença do mercado imobiliário e empreendimentos hoteleiros (CRUZ, 1999). Desse modo, há a inserção de inúmeros setores ligados ao lazer e ao entretenimento, necessários para atender à demanda do fluxo turístico.

Nesse sentido, atendendo à necessidade do desenvolvimento e aos anseios do capitalismo para obtenção de lucros, o turismo influencia a composição espacial e econômica de um local e submete a comunidade autóctone a uma ordem externa típica de uma comunidade litorânea. Os espaços, que anteriormente destinavam-se à residência e aos serviços para a população, começam a ser remodelados com edificações que possam ser utilizadas pelo turismo, resultando até na expulsão dos seus residentes (LUCHIARI, 2000). Desta forma, o local passa a ser constituído de características do turismo, criando e reinventando funções e bens culturais, transformando-os em atrações turísticas, não pelas práticas sociais e relações contidas no local, mas para o recebimento de visitantes.

\section{METODOLOGIA}

\section{MÉTODO}

O objetivo desta pesquisa constitui-se na compreensão da influência do turismo na expansão do espaço urbano de Porto de Galinhas, referenciando-se na reorganização do espaço territorial do local para atender à demanda do turismo, baseada em diversas teorias utilizadas neste trabalho, destacando-se a "Urbanização Turística" de Patrick Mullins (1991), que confirma a influência do turismo na organização territorial do destino turístico, priorizando o atendimento das necessidades desta atividade, tornando-se um local destinado aos visitantes. 


\section{Turismō}

Disponível em: www.univali.br/revistaturismo

A pesquisa utilizou o método descritivo e analítico, por meio da confrontação do referencial teórico utilizado neste estudo com os resultados obtidos, além da abordagem qualitativa na coleta e no tratamento dos dados coletados.

ETAPAS DA PESQUISA

Para a realização deste estudo, a presente pesquisa desenvolveu-se nas seguintes etapas:

Tabela 01 - Etapas da Pesquisa e seus objetivos

\begin{tabular}{|l|l|l|}
\hline Etapas & Passos & Objetivos \\
\hline a Etapa & $\begin{array}{l}\text { Pesquisa bibliográfica com trabalhos de vários autores } \\
\text { essenciais. }\end{array}$ & $\begin{array}{l}\text { Construção do referencial teórico, } \\
\text { discussão e análise dos argumen- } \\
\text { tos e do estado da arte. }\end{array}$ \\
\hline $1^{\text {a }}$ etapa & $\begin{array}{l}\text { Agregação dos achados bibliográficos em suas vivências } \\
\text { da história às argumentações teóricas. }\end{array}$ & $\begin{array}{l}\text { Consolidar os dados coletados em } \\
\text { alguns trabalhos de dissertação e } \\
\text { encarte de jornais. }\end{array}$ \\
\hline & $\begin{array}{l}\text { Coleta e seleção de dados primários, com as entrevistas } \\
\text { com os residentes e os representantes governamentais } \\
\text { de Porto de Galinhas e dos dados secundários, em in- } \\
\text { stituições públicas e privadas e em livros, publicações, } \\
\text { Internet, entre outros. }\end{array}$ & $\begin{array}{l}\text { Complementar o conhecimento } \\
\text { empírico. }\end{array}$ \\
\hline 3a etapa & $\begin{array}{l}\text { Execução da relação dos dados com os três períodos } \\
\text { estudados. }\end{array}$ & $\begin{array}{l}\text { Atingir o objetivo geral do ar- } \\
\text { tigo. }\end{array}$ \\
\hline
\end{tabular}

Fonte: A autora, 2012.

\section{PROCEDIMENTOS METODOLÓGICOS}

Este estudo realizou dois recortes:

- Espacial: Porto de Galinhas e suas áreas periféricas (Praia de Porto de Galinhas, Vila de Porto de Galinhas, Salinas, Socó e Pantanal).

Figura 01- Recorte espacial da área a ser estudada

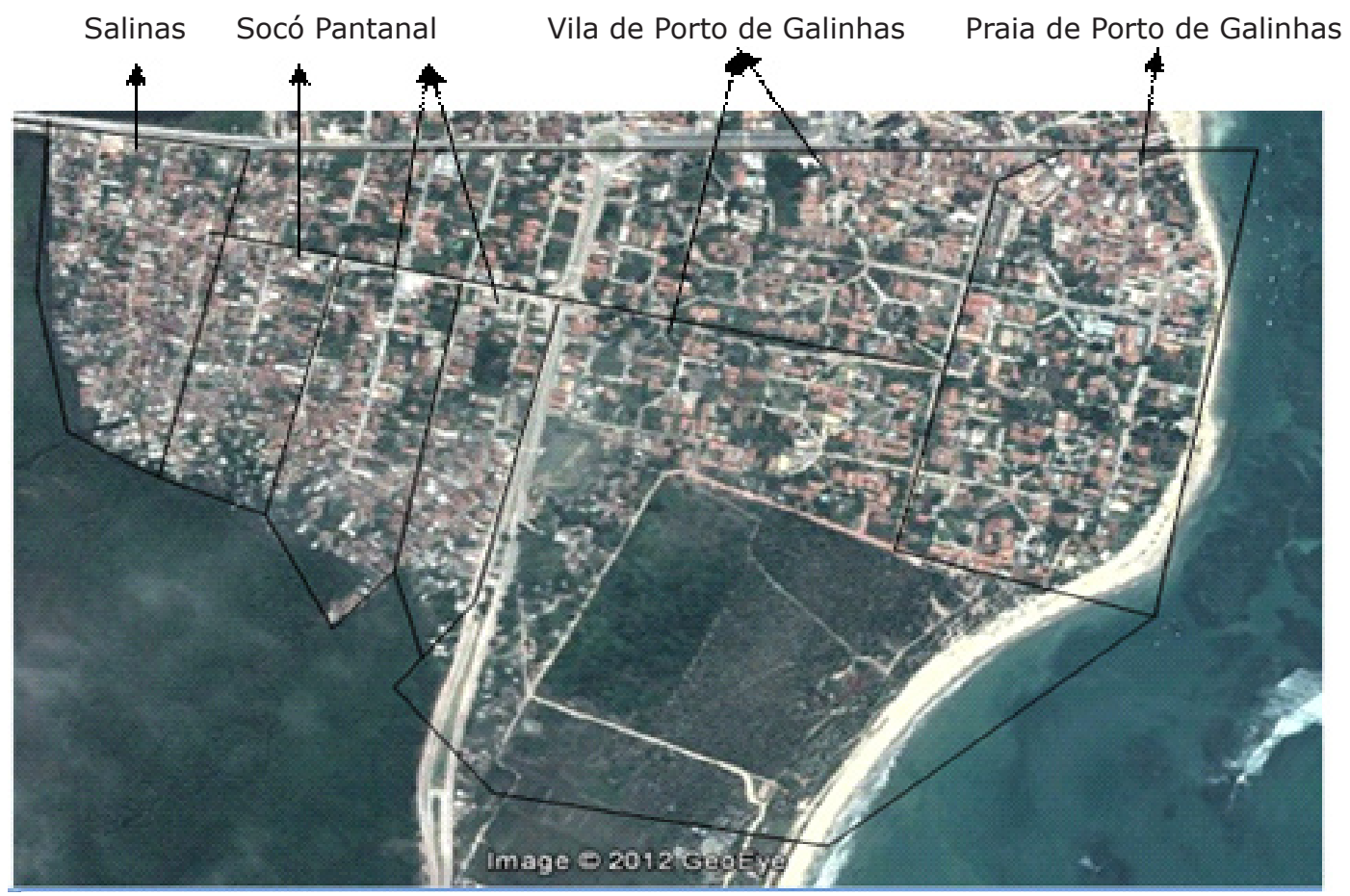

Fonte: Google Earth, 2011.

212 Danielle Mesquita e Gilca Xavier - O turismo e a sua atuação na ... 
-Temporal: O período estudado dividiu-se em três fases, tomando como base os dados históricos coletados, caracterizados de acordo com a mudança da função de Porto de Galinhas pela atuação do turismo no local:

1970 a 1989 - De vila de pescadores à atividade de veraneio e segunda residência

1990 a 1999 - Expansão para o turismo

2000 a 2011 - Porto de Galinhas como um destino internacional

\section{COLETA DE DADOS - AMOSTRA, INSTRUMENTOS E OBJETIVOS}

Entre os meses de agosto a novembro de 2011, houve a aplicação de questionários com os residentes de Porto de Galinhas e das Comunidades Salinas, Socó e Pantanal e entrevistas com os representantes governamentais, pela função destes como poder público e dos dados necessários para o estudo. A pesquisa foi qualitativa, para a complementação e a ampliação das informações obtidas por meio da coleta dos dados secundários, com as seguintes informações:

- Residentes - Mudanças perceptíveis (espacial, econômica e social) a partir do desenvolvimento do turismo em Porto de Galinhas. Houve a padronização das respostas, organizadas pelas semelhanças.

- Representantes Governamentais - Secretaria de Infraestrutura e Serviços Públicos (Investimentos na infraestrutura básica e turística em Porto de Galinhas) e Secretaria de Turismo, Esportes e Cultura (Ações e investimentos para o turismo em Porto de Galinhas).

\section{ANÁLISE DOS DADOS}

As categorias de análise de conteúdo utilizaram duas abordagens: qualitativa e quantitativa.

Tabela 02 - Tipologia das análises realizadas na pesquisa e seus respectivos procedimentos

\begin{tabular}{|l|l|l|}
\hline Análise & Qualitativa & Quantitativa \\
\hline Procedi- & $\begin{array}{l}\text { Cruzamento dos dados com as argumentações teóricas } \\
\text { discutidas no referencial teórico, visando à compreensão } \\
\text { do processo de urbanização e à organização, decorrentes } \\
\text { do turismo em Porto de Galinhas. }\end{array}$ & $\begin{array}{l}\text { Análise dos dados estatísti- } \\
\text { cos censitários provenientes } \\
\text { do Condepe/Fidem e IBGE } \\
\text { e da pesquisa realizada com } \\
\text { os residentes, servindo de } \\
\text { complementação para a aná- } \\
\text { lise qualitativa. } \\
\text { chave das respostas dos entrevistados para o alcance dos } \\
\text { objetivos propostos para a pesquisa. }\end{array}$ \\
\hline
\end{tabular}

Fonte: A autora, 2012.

\section{PORTO DE GALINHAS: DE VILA DE PESCADORES A UM PONTO TURÍSTICO INTERNACIONAL}

\section{0 Á 1989 - PORTO DE GALINHAS: DE VILA DE PESCADORES Á ATIVIDADE DE VERANEIO}

No início da década de 1970, Porto de Galinhas apresentava um núcleo urbano incipiente, com cerca de 200 moradores. Era considerado um local deserto, de ambiência rural, com cobertura vegetal quase intocada, repleta de coqueiros e poucas edificações, como fazendas de cocho e 22 residências, sendo a maioria construída com taipa e madeira e coberta de palha (MENDONÇA, 2004) e, sobretudo, concentrada na Rua Esperança, principal rua da Vila (Figura 02). 
Figura 02 - Porto de Galinhas em 1979

\section{Rua Esperança}

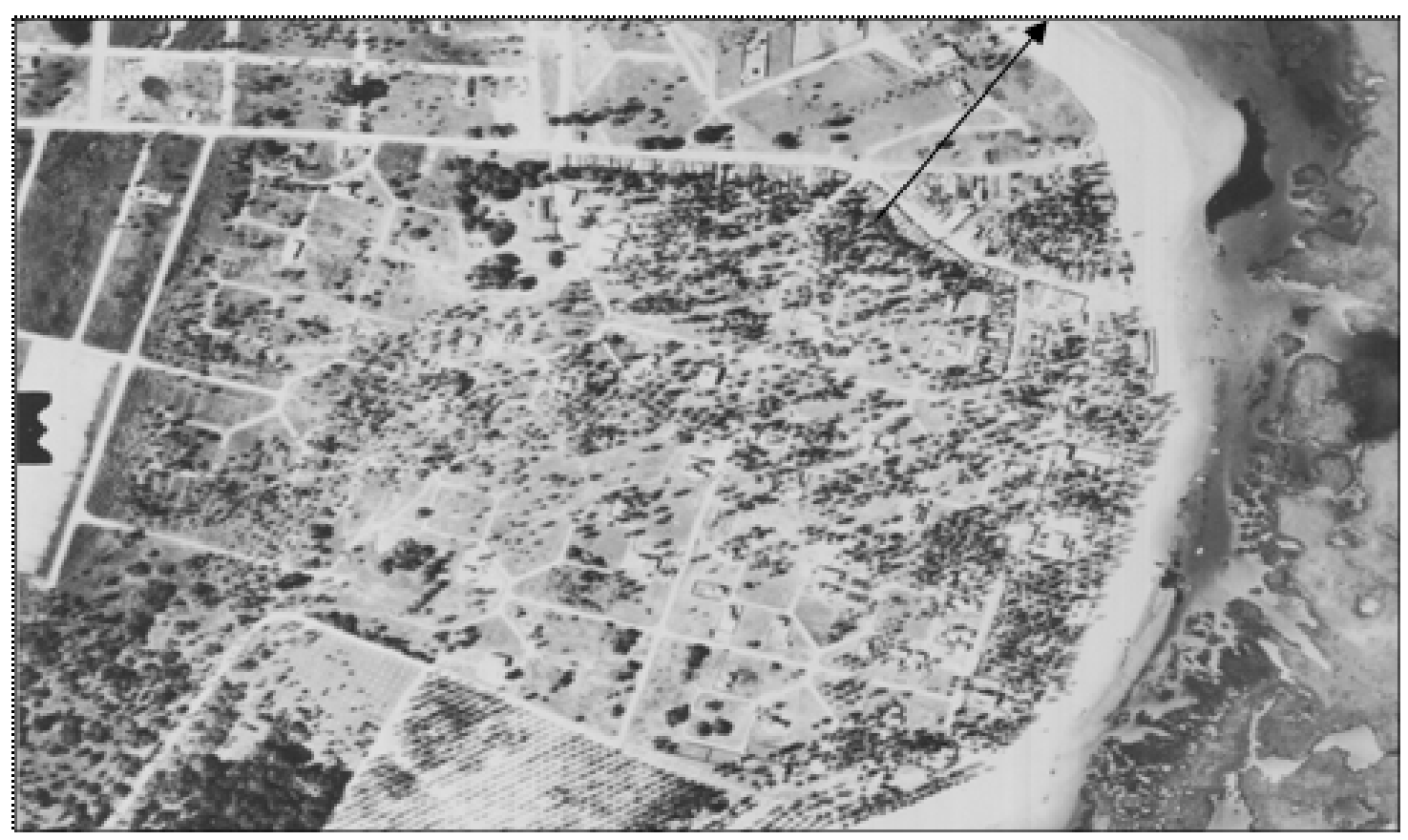

Fonte: Condepe-Fidem, 2011.

O acesso ao local era precário, realizado por uma estreita estrada de terra e palhas de coqueiros (Rua Esperança) dentro da Fazenda Merepe. A falta de energia elétrica dificultava o acesso e a comunicação e apresentava deficiência no saneamento e na água tratada, sendo necessária a instalação de poços artesianos e fossas sépticas (SITE PORTO DE GALINHAS, 2011). Sua base econômica consistia nas atividades ligadas ao setor primário: pesca e agricultura (predominante a exploração do coco).

Em 1975, a implantação do PROÁLCOOL leva a uma crise açucareira em diversos locais que se baseavam nesta atividade, podendo resultar, em Ipojuca, no desemprego da sua população e na invasão dos terrenos da praia de Porto de Galinhas (CPRH, 1999). Neste período, também estava sendo definida a área para a instalação do Porto de Suape, nos limites da Fazenda Cupe e Praia de Gamboa, possibilitando a desapropriação destes locais pelo poder público.

Por estes motivos e pela necessidade de ocupação do território de Porto de Galinhas, em setembro de 1975, a Carvalheira Incorporações e a Ampla, por meio de Mário Jorge, então proprietário da área, dividiu-a em lotes, distribuindo-as as famílias de classe média e alta da região metropolitana de Recife, provocando a derrubada dos coqueiros, das antigas fazendas de coco, no período de 1977 e 1980, para a construção de casas de veraneio.

Nesse sentido, iniciam-se a expansão urbana e a nova organização no território de Porto de Galinhas e, de forma incipiente, a atividade turística no local, por meio da atividade de veraneio, com o surgimento dos Loteamentos do Recanto Porto de Galinhas I (24 de março de 1977) e II (25 de março de 1977) e Merepe I, II e III, desmembrados da Fazenda Merepe, pertencente à Família Uchôa e autorizado pelo Prefeito de Ipojuca Jaime Agostinho, sancionando a Lei no 705, tornando-os uma zona urbana e de turismo. Este fato também impulsiona a implantação de estabelecimentos comerciais, como a Pousada Benedita (1977), a Barraca de D. Biu e as Peixadas do Braz e de Laércio, atendendo aos veranistas que frequentavam o local (BARROS JÚNIOR, 2002).

Além disso, houve o investimento em infraestrutura local, a partir da construção, pelos arquitetos Jerônimo Cunha Lima e Carlos Fernando Pontual, contratados por Mário Jorge, de ruas com 30 metros, praças de 60 m x 60 m e terrenos de 15 m x 45 m (MENDONÇA, op. cit.). Aos moradores da Vila foram reservadas as áreas mais afastadas da praia, deslocando-se para casas de alvenaria. 
Nas décadas de 1970 e 1980, o Brasil começa a se descobrir para o turismo, a partir da identificação do potencial da Região Nordeste para o segmento do turismo sol e mar. Dessa forma, as áreas litorâneas passam a ser destinos turísticos, iniciando uma intensa transformação e valorização do seu território. Houve também o incentivo na implantação de equipamentos e serviços necessários para a atividade turística, oriundos de investimentos privados, nacionais e estrangeiros (CRUZ, 2002).

Em 1974, a área que pertencia ao governo, localizada em Porto de Galinhas (100 ha), foi desmembrada: 19,5 hectares destinou-se à construção da casa de férias do governador do Estado, 86,97 ha permaneceu com o Instituto Agronômico de Pernambuco (IPA), com fins à pesquisa do coco e 3,65 hectares a Empetur, por quase uma década, para o desenvolvimento da atividade do camping, segmento incentivado pelo crescimento da atividade turística e de acampantes em Porto e Maracaípe (MENDONÇA, op. cit).

No mesmo ano, foi realizada a primeira ação de política pública em Porto de Galinhas, por meio do Programa de Ação para o Desenvolvimento do Turismo em Pernambuco pelo Plano Pernambucano de Turismo (PLANPETUR), visando agilizar os projetos de camping, através de recursos da Empetur e Condepe, orçado em 8 milhões de cruzeiros. No entanto, neste projeto, Porto de Galinhas era considerada um local sem atrativos, sendo citada apenas em sua relação com a distância da capital Recife (MENDONÇA, op. cit).

A partir dos estudos realizados pela Fundação de Desenvolvimento Municipal do Interior de Pernambuco FIAM, foi identificada a vocação de Porto de Galinhas para o investimento em mais um segmento do turismo, já que passa a ser considerada propícia à instalação e à operação de um complexo ecoturístico, voltado para a prática de lazer e esportes náuticos. Para isso, foi disponibilizada a distribuição do terreno de 31,44 ha, repartido em 8 lotes a serem adquiridos por pessoas jurídicas, visando à construção de uma estrutura turística receptiva de acordo com a arquitetura e com os princípios urbanos requeridos, aliando a preservação e aos valores dos recursos naturais (GOVERNO DE PERNAMBUCO, 1984).

No final da década de 1970, o Governo Federal realizou ações na infraestrutura, como a inauguração da pavimentação da PE-38 que liga a PE-60 à Nossa Senhora do Ó, distrito onde se localiza Porto de Galinhas, atendendo à necessidades de usinas e meios de hospedagem existentes no local (CRUZ, 2002).

A partir de 1980, o turismo também amplia a sua área de atuação para as praias circunvizinhas (Muro Alto a Maracaípe), com a substituição de inúmeras residências e casas de veraneios por meios de hospedagem: Privê1 de Veraneio (1985) e Privê Portal do Sol em Merepe I, Chalés de Maracaípe (1985) no Pontal de Maracaípe, Armação, Hotel Solar Porto de Galinhas (1986) em Merepe II e Marupiara (1985), Hotel Village (1988) e Pontal de Ocaporã (1989) em Cupe (ANJOS, 2005).

Em 1984, foi criado o termo de referência pela Secretaria de Turismo, Cultura e Esportes do Governo do Estado, para a elaboração de propostas técnicas a serem apresentadas por investidores nacionais e internacionais, com vistas à implantação de empreendimentos hoteleiros na Praia de Porto de Galinhas.

\section{A 1999 - EXPANSÃO DO TURISMO NA VILA DE PORTO DE GALINHAS}

O crescimento da atividade turística resulta na diminuição da cobertura vegetal e do aumento no número das edificações em Porto de Galinhas, concentrando-se, sobretudo, em áreas próximas à praia, por meio do crescimento do comércio local, com o surgimento e a ampliação de diversos meios de hospedagens (20 pousadas, 11 privês, 2 hotéis e 1 albergue) e estabelecimentos comerciais (bares, restaurantes, lojas de grife, souvernirs, entre outros) voltados ao turismo (ANJOS, op. cit). Em 1991, a Vila possuía 122 domicílios particulares e já se encontrava totalmente urbanizada (CONDEPE-FIDEM, 2011) (Figura 03). 
Figura 03 - Vila de Porto de Galinhas em 1997

Rua Esperança

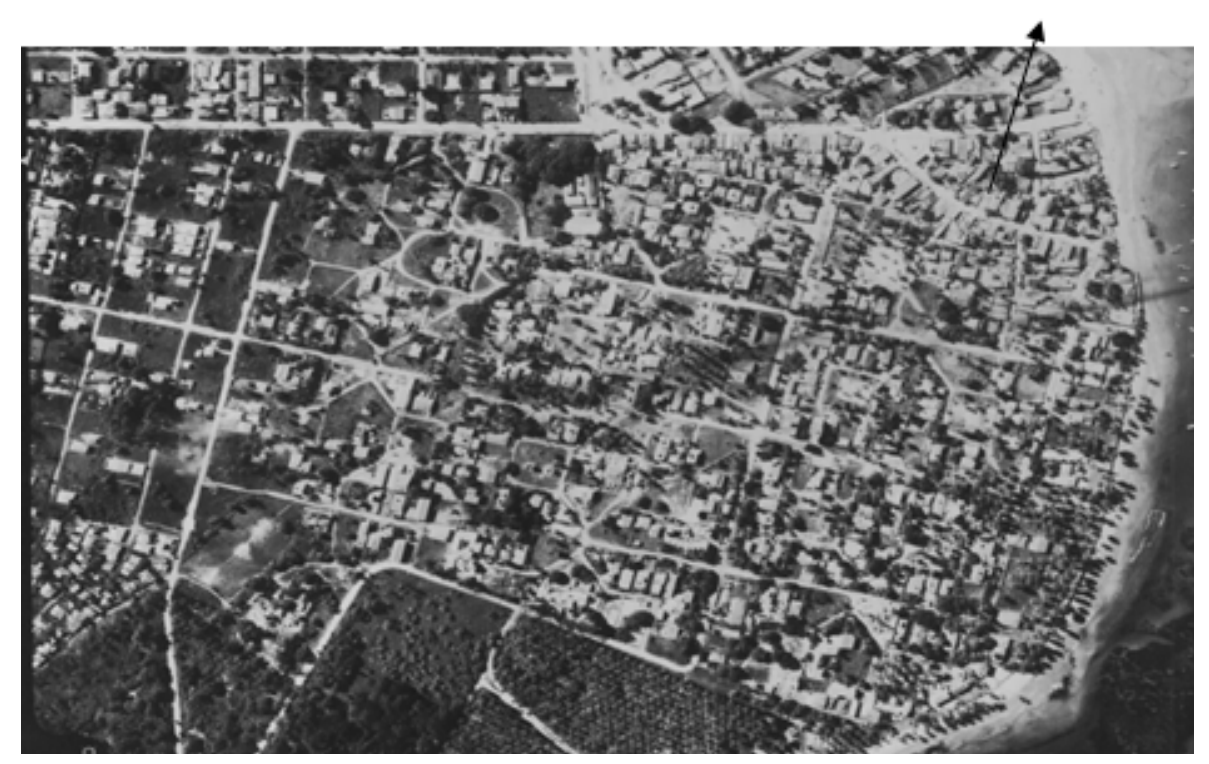

Fonte: Condepe-Fidem, 2011.

Neste período, Porto de Galinhas era constituída de empreendimentos que visavam à preservação do meio ambiente ausente das agitações (ARTIGOS O NORTE, 1992), sendo este fato confirmado pelo depoimento de Carlos Eduardo Zonani, proprietário do Hotel Pontal de Ocaporã em Porto de Galinhas: "Porto de Galinhas continua sendo a praia mais limpa e mais bonita do Nordeste, sem vestígio de poluição ou risco à segurança dos turistas" (DIÁRIO DE PERNAMBUCO, 1992).. No entanto já era previsível a possibilidade do local tornar-se um grande polo turístico, trazendo consigo problemas infraestruturais, como congestionamentos (FOLHA DA TARDE, 1995).

Outro fator que foi impulsionado pelo turismo foi a substituição de diversas residências por estabelecimentos comerciais, ao mesmo tempo em que várias edificações são compostas de dois pisos, sendo o térreo um ponto comercial e o primeiro andar ou a parte de trás uma residência. Parte dos estabelecimentos comerciais é administrada pelos próprios moradores.

Em 1991, há a pavimentação da PE-09, que liga o distrito de Nossa Senhora do Ó a Porto de Galinhas, completando o acesso à Vila (MENDONÇA, op. cit.). No período de 1990 a 1992, há a implantação da infraestrutura básica do local, como a instalação das linhas telefônicas públicas e residenciais e a distribuição regular da energia. No entanto a Vila ainda apresentava deficiência no saneamento básico das redes públicas e estabelecimentos residenciais e comerciais, causando o despejo de fossas e esgotos na praia, comprometendo a infraestrutura e o visual da principal atração do destino de Porto de Galinhas.

No final da década de 90, há o surgimento e a identificação dos impactos decorrentes do crescimento da atividade turística, sobretudo no que se refere ao seu território: uso desordenado do solo por meio de construções de edificações, aliada à falta de infraestrutura e de planejamento, causando a especulação imobiliária, a derrubada da vegetação original, a expansão e a privatização de áreas naturais, a erosão marinha e a erosão nas encostas (CAVALCANTI, 2009). Houve o controle no acesso aos ônibus na Vila, restringindo a 25 unidades, devido ao aumento e à circulação de pessoas e seus impactos (aumento do lixo e congestionamentos) (MELO, op. cit.).

Semelhante a destinos turísticos como Búzios e Tiradentes, a expansão do espaço urbano em Porto de Galinhas também levou a migração de pessoas das cidades próximas, como Sirinhaém e Cabo de Santo Agostinho e no deslocamento de parte da população nativa para áreas mais distantes da praia, resultando no crescimento das comunidades nas áreas periféricas (Socó, Salinas e Pantanal), caracterizadas pela ausência de infraestrutura (MELO, op. cit.). 
Em 1997, houve a elaboração de um termo de referência, por técnicos de diversos segmentos do Governo do Estado e da Prefeitura Municipal de Ipojuca, para a criação de um plano de orientação das ações futuras em Porto de Galinhas, como um sistema de gestão e parâmetros para o uso e para a ocupação do solo, devido à identificação de problemas em relação ao ordenamento do seu território, já mencionadas e mostradas no relatório contido no termo. Segundo o documento, Porto de Galinhas, sendo um destino com potencial consolidado, ainda apresentava características de vila de pescadores e, ao mesmo tempo, continha diversas atividades voltadas para o lazer e para o turismo. No entanto ainda necessitava de infraestrutura para atender à atividade (GOVERNO DO ESTADO DE PERNAMBUCO, 1997).

O Projeto Costa Dourada, pertencente ao Prodetur, visava à transformação de Porto de Galinhas em um polo turístico. Por isso, diversas áreas do local foram repassadas à iniciativa privada com melhorias na infraestrutura, com vistas à construção de diversos empreendimentos.

\section{A 2011 - PORTO DE GALINHAS COMO UM DESTINO INTERNACIONAL CONSOLIDADO}

Porto de Galinhas torna-se um destino internacionalmente conhecido, incluído em pacotes turísticos e divulgado em diversos materiais promocionais, recebendo turistas e visitantes de todo o mundo. O turismo torna-se a principal atividade econômica de Porto de Galinhas, inserindo grande parte da sua população em serviços ligados direta e indiretamente a esta (CONDEPE - FIDEM, 2011).

Neste período, na Vila de Porto de Galinhas intensifica-se a implantação de edificações (Figura 04), com a inserção de diversos estabelecimentos comerciais e meios de hospedagem (privês, pousadas, hotéis e resorts) (MELO, op. cit).

Figura 04 - Porto de Galinhas em 2010

Rua Esperança

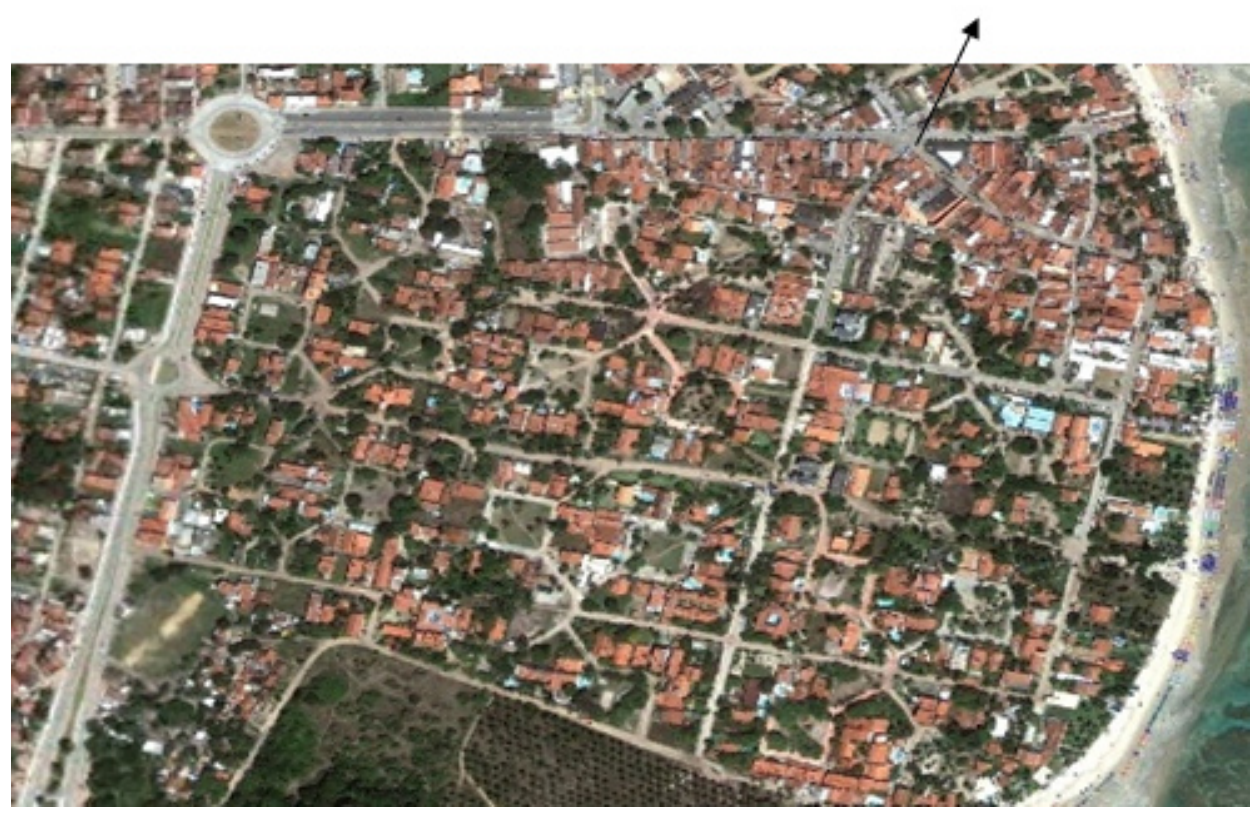

Fonte: Google Earth, 2011.

Neste terceiro período, intensifica-se o comprometimento no saneamento básico e no abastecimento d'água, trânsito caótico nos fins de semana e feriados, som alto nas ruas, aumento da insegurança e consumo de drogas, chegando a ser comparado ao carnaval de Olinda (FOLHA DE PERNAMBUCO, 2001b). 
O crescimento da atividade turística incentivou o uso do solo de forma desordenada, sem a regulamentação necessária para o controle do uso e da ocupação do solo do seu território. Por isso, foi elaborada a lei de ordenamento n²1286, na Câmara de Vereadores, para a elaboração do Plano de Regulamentação de uso e ocupação da orla do município e do Plano Diretor, elaborado pelo Governo do Estado e Fidem, visando à organização e à regulamentação dos espaços, bem como frear a especulação imobiliária e a descaracterização de Porto de Galinhas e de áreas circunvizinhas. A iniciativa também partiu da própria população e dos antigos veranistas

Este documento também previa a limitação ( 3 andares) na construção do número de pavimentos das edificações; possibilidade do estudo de capacidade de carga, por meio da discussão e definição, junto com a população, do limite de pessoas em Porto de Galinhas em épocas de alta estação; e o zoneamento das áreas de turismo para o desenvolvimento hoteleiro e para a preservação ambiental (Zona diversificada (ZRD) e Zona Agro Industrial (ZAI), área urbana e de expansão urbana (divididas em 4 macrozonas urbanas (Ipojuca, Sede, Camela e Nossa Senhora do Ó) e do litoral (Vila de Porto de Galinhas)) com escalas de densidade de expansão urbana (baixa, média e alta) que determina o tipo de construção permitido. Segundo este documento, a Vila foi classificada como sendo alta densidade de expansão urbana, a partir da intensificação, nesta década, na implantação de edificações em Porto de Galinhas.

Em 2001, com recursos do Prodetur II e Alvorada, houve a instalação de 1.800 ligações d'água domiciliares, implantação da rede de esgoto e drenagem, iluminação, pavimentação e sinalização de todas as vias de Maracaípe e Porto de Galinhas.

Em 2003, iniciou-se o Projeto Porto Melhor, projeto de requalificação do espaço urbano de Porto de Galinhas em parceria da Secretaria de Desenvolvimento Urbano do Governo do Estado de Pernambuco com a Prefeitura Municipal de Ipojuca, através do Prodetur II, para saneamento e abastecimento, recuperação de ruas e praças, implantação e melhoria de escolas, delegacias, posto de saúde e centro de informações turísticas, acesso á hotéis e pousadas, abastecimento, saneamento e pavimentação das ruas das comunidades carentes Socó e Salinas, onde vivem parte dos moradores. Mesmo proporcionando melhorias, o projeto recebeu críticas de moradores e empresários, alegando a descaracterização das peculiaridades naturais e rústicas de Porto de Galinhas (MELO, op. cit ).

Em março de 2008, houve reformas na PE-09, que liga Nossa Senhora do Ó a Porto de Galinhas e pavimentação da estrada que liga Vila a Maracaípe. Através do Prodetur II, houve investimentos em ciclovia, pista de Cooper, entre outras, ações orçadas em 12 milhões de reais.

Em março de 2010, houve reformas na PE-09, que liga Nossa Senhora do Ó a Porto de Galinhas e pavimentação da estrada que liga Vila a Maracaípe. Através do Prodetur II (12 milhões de reais), investiu-se na ciclovia, incluindo a PE-09 até a Rua Esperança, pista de Cooper, entre outras. No mesmo ano, a Prefeitura de Ipojuca realizou ações em Porto de Galinhas: cerca de R\$2.155.000,00 em saneamento básico, calçamento das ruas, abastecimento d'água; R\$ 300 mil em iluminação e R\$ 500 mil em limpeza urbana.

No entanto se observa que a sua urbanização ocorre de maneira heterogênea, já que as melhorias na infraestrutura contemplaram, sobretudo, as áreas em que o turismo tem atuado de forma mais acentuada, como a Rua Esperança, enquanto que as ruas mais afastadas da circulação dos turistas, como a Sabará, constituída de casas de moradores e segundas residências, não apresentam calçamento nas vias. Da mesma forma, algumas praças que concentram as residências dos moradores da Vila de Porto de Galinhas não foram beneficiadas com os investimentos em infraestrutura.

Em 2011, Porto de Galinhas era constituída de mais de 200 estabelecimentos voltados, sobretudo, ao turismo, concentrando-se na Rua Esperança, Navegantes e Beijupirá, áreas mais próximas à praia. Em relação ao tipo de serviço oferecido, observa-se que nestas ruas em que há uma maior movimentação de turistas existem inúmeras lojas de souvenirs e opções de alimentação, comuns em locais que se tornam destino turístico, em quantidade maior que um local não turístico. Já as demais ruas, que são menos movimentadas, como Caraúna, Sabará e Poste, são constituídas de pequenos espaços livres, residências, privês e pousadas, sendo equipamentos utilizados pelos turistas.

Nas áreas periféricas, foi identificado que a deficiência na infraestrutura básica é menor em relação à proximidade da Praia de Porto de Galinhas, sendo a comunidade de Salinas a mais distante e a mais precária em serviços básicos, como a ausência da coleta regular de lixo e a existência de um canal a céu aberto na Rua Um (Foto 01) 
Foto 01 - Rua Um na Comunidade Salinas

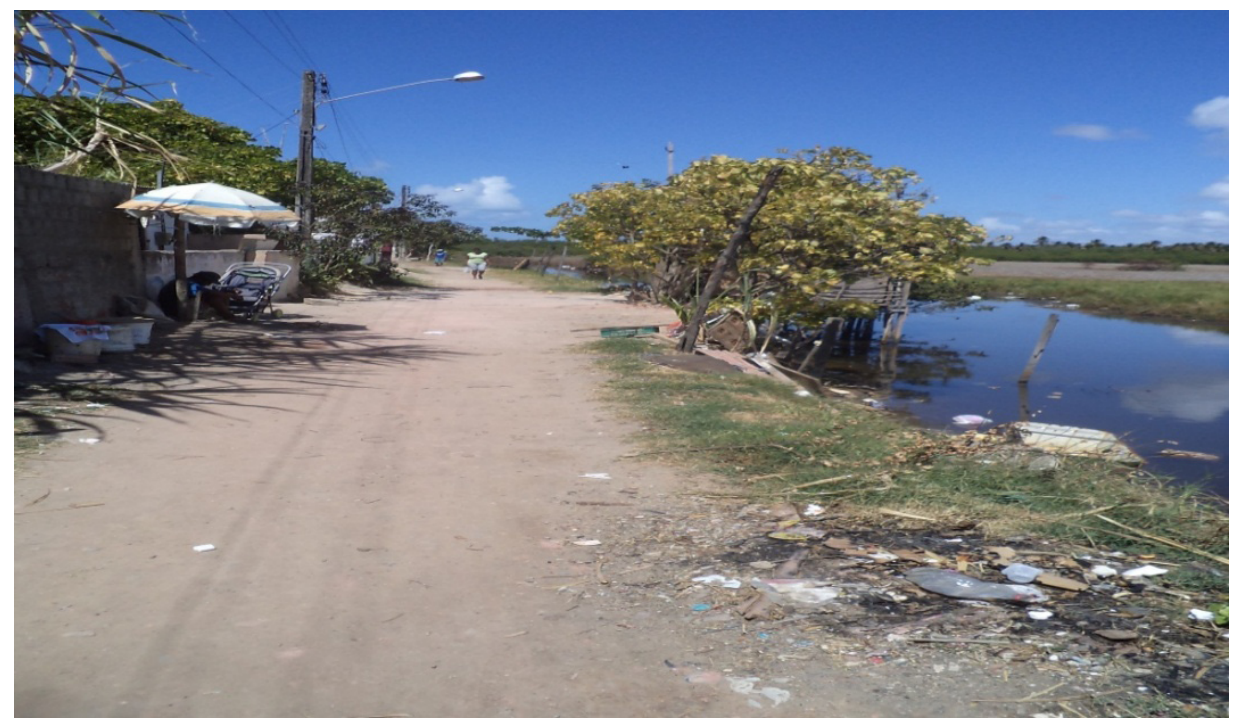

Fonte: A autora, 2012.

A ausência no investimento em serviços básicos também foi identificada na Comunidade Socó. Segundo os moradores, o despejo do esgoto na Rua do Dendezeiro tem provocado o surgimento de doenças como a esquistossomose (Foto 02).

Foto 02 - Rua do Dendezeiro na Comunidade Socó

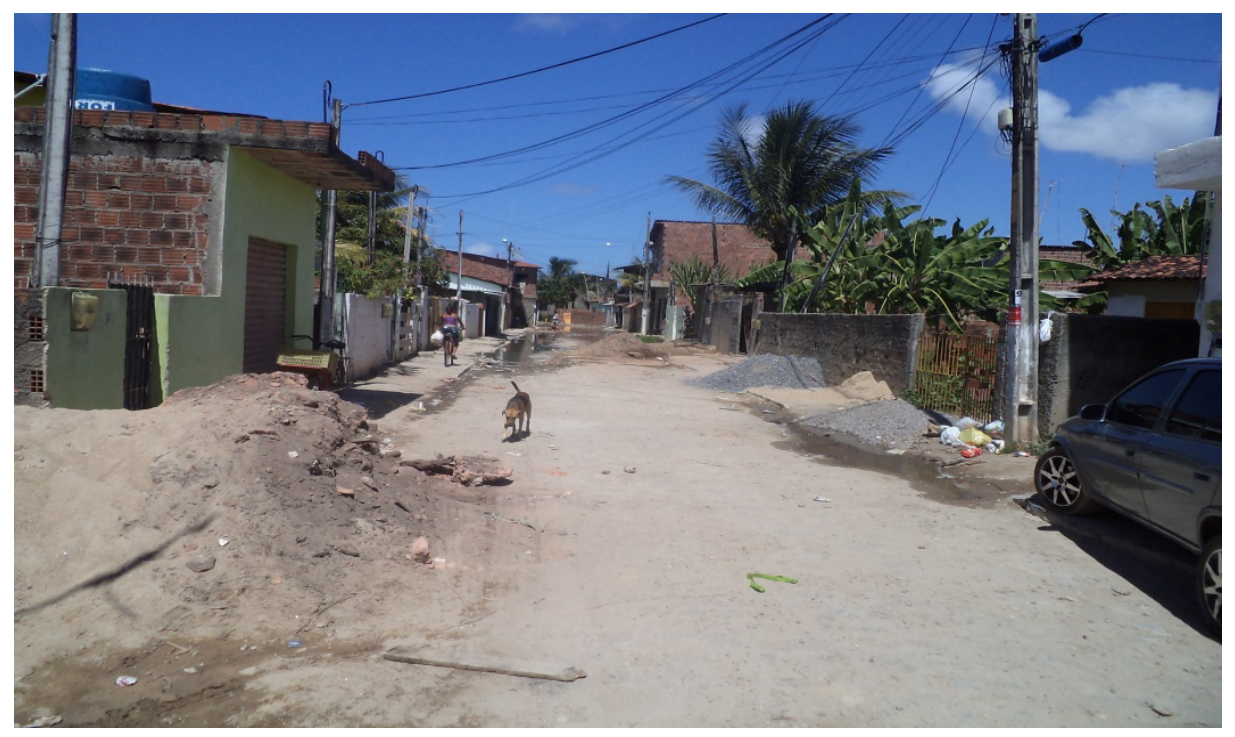

Fonte: A autora, 2012.

Observou-se a mesma precariedade na existência de infraestrutura básica na Comunidade de Pantanal, com a ausência de calçamento e drenagem nas ruas (Foto 03). 


\section{Turismō}

Foto 03 - Comunidade Pantanal II

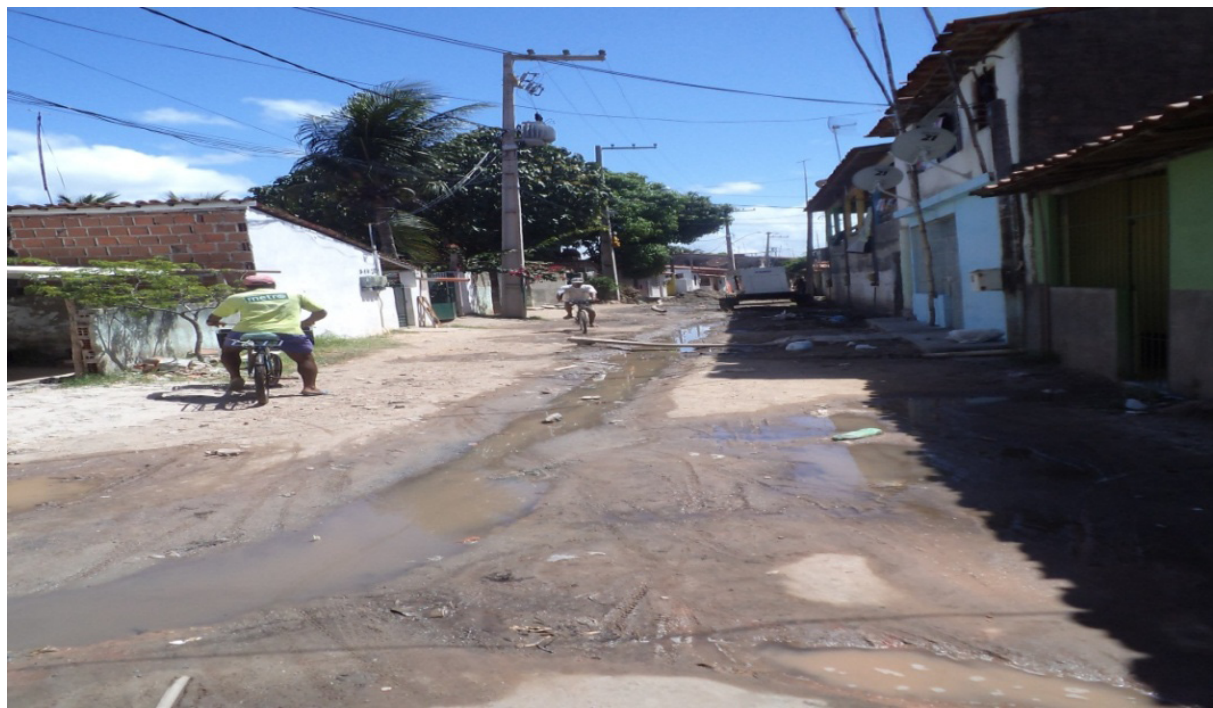

Fonte: A autora, 2012.

Outro fato observado foi a alteração da fisionomia na Comunidade de Pantanal, devido à sua proximidade do Distrito Industrial de Suape. Nesta área, ocorre a construção de privês e conjuntos residenciais destinados à moradia dos profissionais que trabalham no Distrito, sobretudo pessoas vindas do estado da Bahia (Foto 04).

Foto 04 - Construção de privês na Rua Salina Principal - Comunidade Pantanal

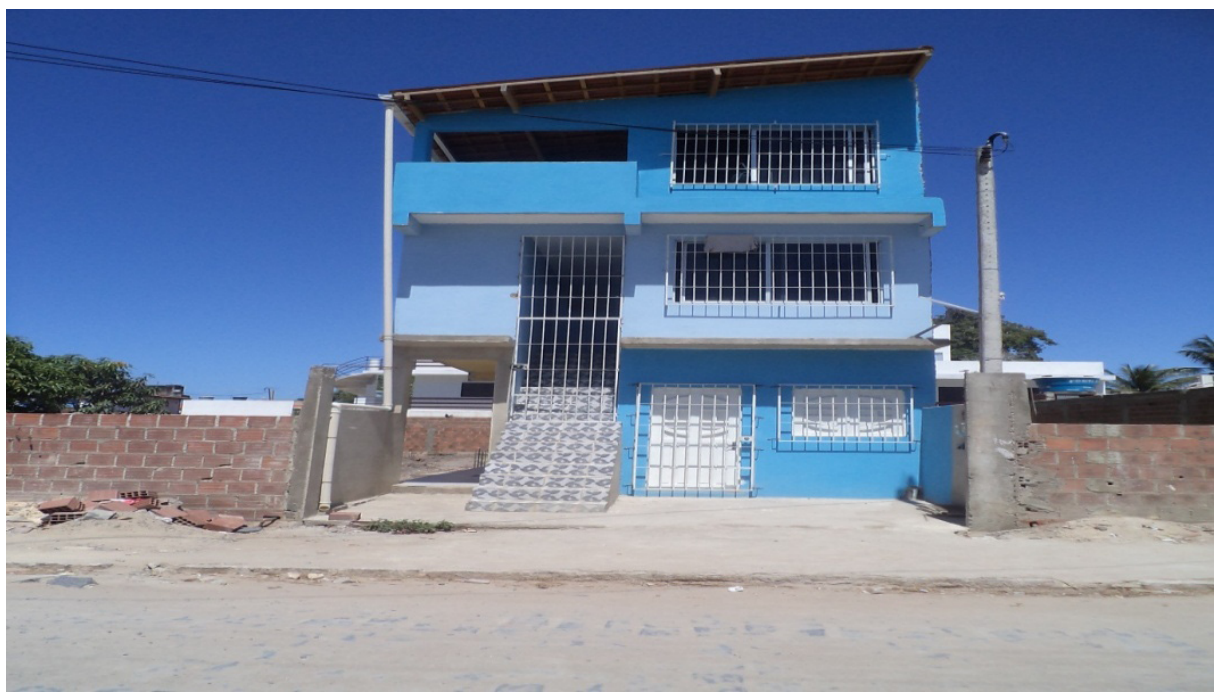

Fonte: A autora, 2012.

\section{O TURISMO E A SUA ATUAÇÃO EM PORTO DE GALINHAS SOB A ÓTICA DOS MORADORES}

Segundo os moradores da Vila e Praia de Porto de Galinhas sobre as mudanças perceptíveis na infraestrutura local (proteção, valorização, provimento e a qualidade de ambiência urbana - praças, ruas, saneamento, conservação de prédios, casas, entre outros) decorrentes do turismo, 98\% dos entrevistados afirmaram que o turismo incentivou o investimento na organização e na pavimentação das ruas. $4 \%$ dos residentes afirmaram que o aumento no número de estabelecimentos do comércio 
é um fator prejudicial, já que os maiores percentuais dos ganhos financeiros concentram-se nos grandes empresários que se instalaram no local, restando para os residentes as "migalhas do turismo".

$6 \%$ dos entrevistados afirmaram que o turismo levou ao processo de valorização das suas edificações, pelo aumento do valor dos imóveis e dos aluguéis cobrados, trazendo benefícios financeiros para os nativos que permanecem em Porto de Galinhas, onde alguns imóveis na Rua Esperança estão avaliados em R $\$ 3$ milhões de reais. No entanto também pressiona a venda das residências para tornar-se comércio, fato confirmado por $4 \%$ dos residentes.

Na entrevista realizada com os residentes das comunidades de Salinas, Socó e Pantanal, 80\% dos moradores afirmaram que não são beneficiados com a atividade turística, já que as melhorias destinam-se apenas à área "da praia". Já 20\% afirmam que o turismo auxilia na geração de emprego e renda, já que parte destes trabalham informalmente na atividade em Porto de Galinhas.

Sobre as mudanças perceptíveis na infraestrutura local (proteção, valorização, provimento e qualidade de ambiência urbana - praças, ruas, saneamento, conservação de prédios, casas, entre outros), todos os entrevistados afirmaram que não há benefícios oriundos do turismo.

\section{O TURISMO E A SUA ATUAÇÃO NO PROCESSO DE URBANIZAÇÃO E ORGANIZAAÇÃO DA VILA DE PORTO DE GALINHAS}

O território de Porto de Galinhas tem sido fruto das alterações ocorridas ao longo do seu processo histórico, sobretudo pelas mudanças na economia local, resultando em uma nova forma (configuração) para atender a uma nova função (atividade econômica).

De 1970 a 1989, quando se baseava na pesca, Porto de Galinhas era rústica e apresentava características de área rural, ausência de serviços básicos e pouco urbanizada, comum nas localidades que se baseavam nas atividades de extração de coco e pesca. O crescimento do turismo intensificou as mudanças urbanas e socioeconômicas da Vila, com a diminuição e a substituição das atividades econômicas anteriores e o enfoque no turismo, tornando-se um local totalmente urbano e, sobretudo, comercial, por meio do surgimento e do aumento no número de meios de hospedagens e estabelecimentos comerciais em Porto de Galinhas, voltados principalmente para atender à nova demanda e às necessidades.

A implantação e a concentração de empreendimentos voltados ao turismo podem ser notadas desde a sua formação, a partir da distribuição das terras, visando à construção de segundas residências. Nesse período, a atuação do turismo incentivou, ainda de forma incipiente, a expansão urbana, atendendo a uma necessidade local de ocupação do solo, a partir do surgimento dos loteamentos e a consequente distribuição das terras. Esse movimento gerou a substituição das fazendas de açúcar e o avanço às áreas naturais para a implantação das casas de veraneio e praças, dando início às alterações na sua formação original, intensificando-se no final da década de 80 e início dos anos 90.

Além disso, forças externas também influenciaram a expansão urbana de Porto de Galinhas com a descoberta do potencial do litoral nordestino para o desenvolvimento do turismo nacional, como turismo sol e mar, sendo uma atividade econômica bastante rentável e com retorno em curto prazo. A partir desse fato, recebeu investimentos de projetos governamentais e incentivos privados, a partir da implantação de infraestrutura básica e turística, visando à construção de equipamentos turísticos.

Desse modo, o território de Porto de Galinhas foi reconfigurado a partir dos interesses e necessidades do turismo, que, enquanto atividade econômica, necessita de subsídios para a sua atuação, tornando-se, então, a matéria prima para o desenvolvimento da atividade. Ademais, foi um grande influenciador na questão da infraestrutura e da pavimentação das ruas, além da valorização das residências existentes, conforme descrito pelos moradores na pesquisa realizada. No entanto vale salientar que, a partir do momento que um local se torna um destino turístico, as alterações que acontecem com o desenvolvimento desta atividade são necessárias, já que, pela própria definição do turismo, o destino precisa proporcionar facilidades para a estada dos visitantes a partir da existência de equipamentos como hospedagem, o que resultaria em mudanças espaciais e urbanas. 
Nesse sentido, a atividade turística possui forte relação com a expansão urbana de Porto de Galinhas, visto que, atualmente, o local caracteriza-se, principalmente, por estabelecimentos comerciais voltados para atender aos turistas, além do maior investimento em infraestrutura nas ruas em que há maior circulação de moradores e visitantes.

No entanto, de acordo com o que foi detectado ao longo da pesquisa, identificou-se que Porto de Galinhas apresenta uma disparidade entre os investimentos infraestruturais, sendo as maiores beneficiadas aquelas áreas em que o turismo apresenta-se mais atuante. Esse fato também confirma a ocorrência da urbanização turística e heterogênea em Porto de Galinhas, onde as áreas mais utilizadas pelo turismo apresentam características da atividade e são priorizadas nos investimentos em infraestrutura básica e turística.

Além disso, houve a segregação socioespacial com parte dos residentes antigos da Vila, que foram "empurrados" para as áreas periféricas a partir da implantação da atividade turística. Ao contrário das áreas mais próximas à praia, as comunidades de Socó, Salinas e Pantanal caracterizamse por serem excluídas das melhorias no investimento na infraestrutura provenientes do turismo, sendo confirmado pelas entrevistas realizada com os moradores. O fato de essas áreas não serem contempladas economicamente pela atividade, pode justificar o investimento na implantação de privês e residências voltadas para a hospedagem e para a moradia dos profissionais que trabalham no Distrito Industrial de Suape, tornando-se mais rentáveis que o investimento para o turismo.

Nesse sentido, o turismo proporciona melhorias para aqueles que residem na Vila de Porto de Galinhas. No entanto não contemplam a população que reside nas comunidades de Socó, Salinas e Pantanal, sendo excluídas dos benefícios que essa atividade pode proporcionar.

\section{CONSIDERAÇÕES FINAIS}

O turismo gera mudanças urbanas, sociais, econômicas, entre outras, pela possibilidade de se relacionar com as diversas áreas de um local, tanto de forma direta, como indireta. No caso de Porto de Galinhas, a introdução do turismo leva a uma série de mudanças na urbanização, na dinâmica populacional e socioeconômica. A simples e rústica vila de pescadores, em cerca de 40 anos, transformou-se em um dos pontos turísticos mais conhecidos de Pernambuco, com alterações que, muitas vezes, sequer faz lembrar os seus traços de um passado recente.

Crescer e expandir não significa desenvolver. O turismo como causador do processo de expansão urbana deve focar a contribuição primeiramente para os residentes, no que se refere à infraestrutura básica, como saneamento, saúde, transporte, entre outros. Observa-se que Porto de Galinhas possui enfoques exclusivos para o turismo e ainda necessita do investimento em sua infraestrutura.

Sobre a urbanização, observa-se a proximidade do Complexo Portuário de Suape e Porto de Galinhas como um novo agente para a urbanização do local, a partir do investimento em residências para os profissionais que atuam neste Complexo, levando a efeitos socioeconômicos e urbanos, tanto positivos como negativos.

O turismo proporcionou benefícios para uma parte da população que ainda permanece em Porto de Galinhas, mas não insere parte dos seus residentes que se deslocou para as áreas periféricas. Diante disso, é necessário que se tomem medidas para a diminuição dessas desigualdades, necessárias até para o próprio desenvolvimento do turismo, evitando a insatisfação por parte dos residentes, principalmente das comunidades de Socó, Salinas e Pantanal.

Nesse sentido, o planejamento urbano e turístico pode favorecer a atividade turística na Vila de Porto de Galinhas, no que se refere à avaliação e ao controle das atividades e seus respectivos impactos produzidos, visando a uma diminuição do processo de expansão e deterioração da cobertura vegetal, conciliando a preservação dos recursos naturais, matéria-prima para atração de visitantes para o destino e uma expansão urbana e desenvolvimento da economia, alcançando contribuições socioeconômicas para a maioria dos seus atores, principalmente a comunidade receptora. Estas ações ajudarão na atuação do turismo a longo prazo e de forma mais benéfica para todos em Porto de Galinhas. 
ANJOS, Kainara Lira dos. Turismo em cidades litorâneas e seus impactos ambientais urbanos: O caso Porto de Galinhas - PE. Dissertação (mestrado). Pós Graduação em Desenvolvimento Urbano. Universidade Federal de Pernambuco. Recife, 2005.

ARTIGOS O NORTE. Porto de Galinhas: Cenário histórico de raras belezas. Turismo. 26 de junho de 1992.

BARROS JÚNIOR, Francisco de. Dinâmica Espacial e a Reorganização Territorial do Litoral de Ipojuca: Porto de Galinhas - A Emergência de um Espaço Turístico. Dissertação (Mestrado). Departamento de Ciências Geográficas. Universidade Federal de Pernambuco, 2002.

-BECKER, Berta. O Uso Político do Território: questões a partir de uma visão do terceiro mundo. In: BECKER, Berta K.; COSTA, Rogério K.; SILVEIRA, Carmen B. (Org.) Abordagens Políticas da Espacialidade. Rio de Janeiro. Rio de janeiro: UFRJ, 1983.

BERNAL, Maria Cleide. Turismo e Especulação Imobiliária no Nordeste. Revista de Debate da Fase. Proposta no 121. p. 25 a 29.

BENI, Mário Carlos. A política do turismo. In: TRIGO (Org.). Turismo. Como aprender,como ensinar. São Paulo: SENAC, 2001. v. 1.

CARLOS, Ana F. Alessandri. "Novas" contradições do espaço. In: DAMIANI, Amélia Luisa et al. (Orgs.). O Espaço no fim do século: a nova raridade. São Paulo: Contexto, 1999.

CASTILHO, Jorge Moura de. Turismo: uma prática sócio-espacial que se redefine e uma nova perspectiva de análise do espaço geográfico. In: Revista de Geografia. v.15, n.1, jan/dez. UFPE. Recife:1999.

COELHO, Maria Célia Nunes. Impactos ambientais em áreas urbanas: teorias, conceitos e métodos de pesquisa. In: GABRA, Antonio José Teixiera; CUNHA Sandra Batista da. (org.) Impactos ambientais urbanos no Brasil. Rio de Janeiro: Bertrand Brasil, 2001 p. 19-45.

-COMPANHIA PERNAMBUCANA DE MEIO AMBIENTE. Diagnóstico Sócio-Ambiental \& ZeEC - Zoneamento Ecológico Econômico Costeiro do Litoral Sul de Pernambuco. Recife. CPRH: 1999. 91 p.

CORRÊA, Roberto Lobato. O espaço urbano. 4. ed. 3a impressão. São Paulo: Ática, 2002.

CRUZ, Rita de Cássia.Política de Turismo e Território. 3. ed. São Paulo: Contexto, 2002(coleção turismo)

CRUZ, Rita de Cássia. Geografias do turismo: de lugares a pseudo-lugares. São Paulo:Roca „2007.

DEÁK, Csaba. Rent theory and the price of urban land Spatial organization in a capitalist economy, 1985.

FOlHA DE PERNAMBuCO. Porto vivou praia da baderna. Balneário mais famoso do estado não tem dono. 6 de novembro de 2001 b.

GOVERNO DO ESTADO DE PERNAMBUCO. Secretaria de Planejamento. Secretaria de Indústria, Comércio e Turismo, Secretaria de Ciência, Tecnologia e Meio Ambiente. Prefeitura Municipal de Ipojuca. Plano diretor de desenvolvimento turístico do litoral de Ipojuca e ordenamento e requalificação urbana de Porto de Galinhas. Termo de Referência. Proposta para discussão. Recife, abril de 1997.

CPRH. Plano de Ação Integrada Litoral Sul, Ipojuca. Programa de Gerenciamento Costeiro de Pernambuco, 1997.

CONDEPE\FIDEM. Desenvolvimento Humano na Região Metropolitana do Recife. Recife, 2011. Atlas Metropolitano Recife, 2011. CD-ROM.

CAVALCANTI, Rosita Oliveira. Porto de Galinhas: O turismo e a questão ambiental. Monografia (Especialização). Especialização em ensino de Geografia. Departamento de Ciências Geográficas. Universidade Federal de Pernambuco. Recife, 2009.

DIÁRIO DE PERNAMBUCO. Porto de Galinhas fortalece o turismo. A beleza natural, cercada por igrejas do século XVII, conta com uma bem montada rede hoteleira. Cidades. Recife, domingo, 26 de abril de 1992. 
FOLHA DA TARDE. Piscina natural garente a diversão. São Paulo, 5 de junlho de 1995.

FONSECA, Maria Aparecida Pontes da; COSTA, Ademir Araújo da. A racionalidade da urbanização turística em áreas deprimidas: o espaço produzido para o visitante. In: Mercator - Revista de Geografia da UFC. Ano 3, n.6. 2004. p. 25-32.

-GOVERNO DE PERNAMBUCO. Secretaria de Turismo, Cultura e Esportes. Empresa Pernambucana de Turismo. Termos de Referência para os projetos executivos dos equipamentos que comporão o distrito ecoturístico de Porto de Galinhas. Julho de 1984

-JACQUIN, A.; MISAKOVA, L.; GAY, M. A hybrid object-based classification approach for mapping urban sprawl ing periurban environment. Landscape and Urban Planning, v. 84, n. 2, p. 152-165, fev 2008.

LEAL, Suely. M. Ribeiro. Processos e transformações na configuração dos espaços urbanos: como se movem e quais papéis desempenham os atores imobiliários na Região Metropolitana do Recife. In: Proposta Revista Trimestral de Debate da Fase, Ano 34, No 121, 2010.

LIMA, Clarisse Vasconcelos Fraga de Melo. Urbanização turística no Litoral Sul de Pernambuco: o caso do município de Tamandaré. Dissertação. Universidade Federal de Pernambuco. Programa de Pósgraduação em Geografia. Recife, 2006.

LUCHIARI, Maria Tereza D. P. Urbanização turística: um novo nexo entre o lugar e o mundo. In: SERRANO, Célia; BRUHNS, Heloísa Turini \& LUCHARI, Maria Tereza D. P. (Orgs.) Olhares contemporâneos sobre o turismo. Campinas: Papirus, 2000. pp.105-130. (Coleção "Turismo").

MASCARENHAS, G. Cenários contemporâneos da urbanização turística. Caderno Virtual de Turismo. No 4 vol. 4, 2004. Disponível em: <http://www.ivt.coppe.ufrj.br/caderno/ojs/include/getdoc. php id $=957 \&$ article $=67 \&$ mode $=$ pdf $>$. Acesso em 20 de agosto de 2011 .

MATTOS, Carlos A. de. Globalización, negócios inmobiliarios y transformación urbana. Revista NUEVA SOCIEDAD. No 212, noviembre-diciembre de 2007, ISSN: 0251-3552, <www.nuso.org>. Acesso em: 10 de novembro de 2011.

MELO, Maria Emília. Sustentabilidade e Responsabilidade Social na Cadeia do Turismo. O caso da Praia de Porto de Galinhas em Ipojuca-PE/Brasil. Relatório de Pesquisa. Rio de Janeiro, janeiro de 2006.

MENDONÇA, Luis Carvalho de (Org.). A Invenção de Porto de Galinhas: História, empreendedorismo e turismo. Recife: Persona, 2004.

MULLINS, Patrick. Tourism urbanization. International Journal of Urban Regional Research, 15 (3): 326-342, 1991.

RASFFETIN, Claude. Por uma geografia de poder. São Paulo: Ática, 1993.

RODRIGUES, Adyr Balastreri. Território, patrimônio e turismo de base local - uma relação inequívoca. In: SEABRA, Geovanni (Org.) Turismo de base local: Identidade Cultural e Desenvolvimento Regional. João Pessoa: Universitária UFPB, 2007.

RUSCHMANN, Doris Van de Meene. Turismo e Planejamento Sustentável: a proteção do meio ambiente. 11. ed. Campinas, SP: Papirus, 2004.

SANTOS, Milton. Metamorfoses do Espaço Habitado, fundamentos teórico e metodológico da geografia. São Paulo: Hucitec, 1996.

. O retorno do território. In: OSAL: Observatório Social de América Latina. Ano 6 n. 16 vol (jun.2005). Buenos Aires: CLACSO, 2005. ISSN 1515-3282. Disponível em: <http://bibliotecavirtual. clacso.org.ar/ar/libros/osal/osal16/D16Santos.pdf>. Acesso em 03 de maio de 2011.

A urbanização brasileira. São Paulo, Hucitec, 1993.

SAQUET, Marcos Aurélio. Território e Desenvolvimento: diferentes abordagens. Francisco Beltrão: Unioeste, 2004.

SASSEN, Saskia. As cidades na economia mundial. Tradução: Carlos Eugênio Marcondes de Moura. São Paulo: Studio Nobel, 1998 [Coleção Megalópolis]. 
SELVA, Vanice Santiago Fragoso. Organização espacial urbana de Natal. Dissertação de Mestrado. Recife: Universidade Federal de Pernambuco, 1988

SITE PORTO DE GALINHAS. Fotos de Porto de Galinhas. Disponível em: <http://www.portodegalinhas. com.br/arnaudmattoso/fotos.htm>. Acesso em: 10 de novembro de 2011a

SOUZA, Marcelo José Lopes. O território: sobre espaço e poder. Autonomia e desenvolvimento. In: CASTRO, I. E. de; GOMES, P. C. da C.; CORRÊA, R. L. (Orgs.). Geografia: Conceitos e temas. Rio de Janeiro: Bertrand Brasil, 2001.

SOUZA, Marcelo Lopes. Mudar a Cidade. Rio de Janeiro: Bertrand Brasil, 2006.

TELES, R. M. de S. A importância do território na prática do planejamento turístico - reflexões acerca do Brasil. In : RUSCHMANN, D. V. M. ; SOLHA, K. T. (Orgs.) Planejamento Turístico. Barueri: Manole, 2006.

\section{NOTAS}

1 Neste artigo, o termo privê consiste em um tipo de alojamento que se assemelha à segunda residência que consiste um uma "[...] imóvel próprio para utilização em férias, fins de semana e feriados prolongados, em condomínio horizontal, conjunto habitacional, casa isolada e outros". (BENI, 2001, p. 329). 